\title{
Evaluation of Village Autonomy in Indonesia (An Analysis Study of Village Autonomy in Pekarungan Village, Sukodono Sub-District, Sidoarjo District)
}

\author{
Endang Indartuti \\ Student of Doctor Study Program of Administration Sciences - FISIP, Universitas 17 Agustus 1945 Surabaya, \\ Jl. Semolowaru No. 45 Surabaya, Jawa Timur, Indonesia \\ V. Rudy Handoko
}

I.B. Wirawan

Uthe Ch. Nasution

\begin{abstract}
At the beginning of the reform era in Indonesia brings changes to the structure of the Government System in the regions, especially villages. This condition is marked by the transition from a change of the new order era with a centralized regime towards a reform era, a new and more open regime with decentralization. The wind of reform is carried over to the latest regulation (Law No.6 of 2014). This law seeks to restore village autonomy based on its origins and customs as a process of restoring state confidence in the village. On the other hand, to fulfill its political promise, the provision of village funds as a source of village income that aims to make the village independent shows that this law is still the same with the previous one, that in the village there is still supra village power. Village funds make all forms of implementation and management of village finances must be used in accordance with the village financial system. The existence of this system makes the village authority no longer in accordance with the principles of village autonomy, that village autonomy is in accordance with its origins and customs. Giving village autonomy with financial management through the Village Financial System (SISKEU) is felt that the portion of creativity and space for the village is limited. This triggers a lack of courage of the village officials to take the initiatives in making policies for a better village development. This situation is experienced by all villages in Indonesia, such as Pekarungan Village. This study uses a qualitative research method. The key informant is a Former Head of Pekarungan Village for 2 consecutive periods (1991-2006). He understands very well the changes in the laws governing the village. The result of the research shows that based on the principles of Kartohadikusumo's autonomy, autonomy can be implemented if there are inherent rights in the village, namely: "(1) the right to own territory with legal boundaries; (2) the right to elect and appoint the head or assembly of the village administration; (3) the right to administer and govern the village households; (4) the right to own and manage village assets and finance; (5) the rights to own village land; (6) the right to collect local taxes. Without the inherent rights mentioned above, autonomy is difficult to be implemented ".Based on the effectiveness of success in achieving the goals set and the relationship between the expected results and the results achieved, there are some rights that are not exercised as they should. In connection with village rights in Law No. 6 of 2014 concerning Villages, (1) the village regulates and manages community interests based on the origin, customs, social, and cultural values of the village community; (2) the village determines and manages its institution; and (3) the village receives sources of income, including village funds. All sources of village income, such as the Village Cash and village financial management, must be based on the village SISKEU as determined by the government bureaucracy.
\end{abstract}

Keywords: Evaluation, Village Autonomy

DOI: $10.7176 /$ PPAR/10-6-08

Publication date:June 30th 2020

\section{A. INTRODUCTION}

At the beginning of the reform era in Indonesia brings changes to the structure of the Government System in the Regions, especially Villages. This condition is marked by a transition from the new order era with a centralized regime towards a reform era, a new regime that is more open to decentralization. This change is marked by the issue of Law No. 22 of 1999. At that time, there is a new era in the structure of power relations in government, that is the power relations between the Central and Regional Governments. Law No. 22 of 1999 is a merger of Laws No. 5 of 1974 and No. 5 of 1979. The substance of the two previous laws reflects the idea of centralism, whereas the new law is more representative of a decentralized mind. Because it is a combination of the two laws, Law No. 22 of 1999 regulates not only the structure of the management of relations between the central and regional (district) governments whose substance is on the idea of regional autonomy, but also its relationship with 
village government whose substance is also on the idea of village autonomy.

The existence of laws governing the village continuously develops and changes, such as Law no. 22 of 1999 became Law No. 32 of 2004 concerning Regional Government. The most recent change is Law No.6 of 2014 concerning Villages that have separated the Village arrangements from the Regional Government. Law No. 6 of 2014 is followed up by Government Regulation No. 47 of 2015 concerning Amendments of Government Regulation of 43/2014. The last is the issue of Government Regulation No. 11 of 2019 concerning the Second Amendment of Government Regulation No 43 of 2014 concerning Regulations for Implementing Law 6 of 2014 concerning Villages signed on February 28, 2019 by the Indonesian President Joko Widodo. The Law Amendments basically regulate the village autonomy.

Based on the above categories, the picture of village autonomy in Indonesia follows the development of economic politics at that time. In Law No.6 of 2014, village autonomy is based on the rules of the higher governmental regulations called local self- government. In other words, the village government system gives the authority to manage and regulate its household and its own people interests, based on Government/State provisions, especially in planning and budgeting. Consequently, the village autonomy becomes increasingly shackled. The village in running its administration is based on five principles: representation, transparency, accountability, responsiveness, and participation. The five principles are elaborated in the form of a planning and budgeting system determined by a government bureaucracy that the purpose is different every year. The system is called the Village Financial System (SISKEUDES). Why does village autonomy become shackled? This is because SISKEUDES is a system created to facilitate the Central Government, Provincial Regional Governments, and Regency/City Regional Governments in structuring villages.

In other words, SISKEUDES can cancel the planning priorities made by the village, because it is a system. If the planning concepts are different, they will be automatically rejected. It seems that the village autonomy has not yet been fully granted to the village. There is still supra village power. It will be better, if the final authority and decisions related to the village are given entirely to the village, not vice versa. The current law shows that the village autonomy is still limited in putting villages as a subsystem of a larger system, that is the United State of the Republic of Indonesia (NKRI).

The village autonomy in Indonesia comes from the "gift" of the Government as regulated by Law or Government Regulation. It is not based on traditional rights. Therefore, the existence of village autonomy in Indonesia is necessary to be studied to evaluate Law No.6 of 2014. The village autonomy in the new law is either getting further away or in accordance with its principle. Based on the Village Financial System, is the village's authority in making the planning in accordance with the principle of village autonomy or not?

In fact, the Village Finance System (SISKEU) limits the portion of the village's creativity and space. It triggers a lack of courage for village officials to take initiatives in making policies for a better development. For example, there are some emergent conditions that need a lot amount of funds. Because they are not included in SISKEU, a village head must first use his personal funds. If the activities are not fit with the SISKEU priority points, the funds cannot be reimbursed. On the other hand, there are many opportunities of funding sources for village development through development programs, such as funds from State Budget and Income (APBD) of District, Village Budget and Income (APBDes), village fund allocation, decentralized funds, co-administered task funds, and the National Community Empowerment Program (PNPM) fund. However, the village cannot use maximally these funds. Therefore, it needs a change to return to the principle of village autonomy, that the village government is given the authority to manage and regulate the interests of their own communities based on Government/State provisions. The issue of the SISKEU policy by the government is currently considered to kill the village creativity. The regulatory reform should not neglect the inherent village autonomy principles.

Based on the problem formulation, the important questions raised are:

1. Does Law No. 6 of 2014 make village autonomy even further or in accordance with the principle of village autonomy?

2. Does Law No. 6 of 2014 make village authority in structuring, and planning village development in accordance with the principle of village autonomy?

3. Does the Village Financial System in Law No. 6 of 2014 make village authority broader or narrower based on the principle of village autonomy?

\section{B. THEORITICAL REVIEW}

\section{Public Policy Concepts}

Studies conducted by Thomas R. Dye (1998), James E. Anderson (1999), and Charles Lindblom (2007) state that policy is closely related to decision making because it essentially chooses the available options. Meanwhile, the term "public" shows the broad definition. In this case, it can be said that "the public" is closely related to the state, the market, and civil society. They then become actors in the public arena. So the public can be defined as a dimensional space that reveals the interaction of the three actors.

Furthermore, Ch. O. Jones (1984) and Amol Beanal (2005) state that the term "public policy" refers to a 
broader set of implementation tools that includes budgets and implementing structures. It can be explained that the public policy cycle relates to making, implementation, and evaluation of policy. Public involvement in each stage of the policy becomes a measure of the compliance level of the state, organization, or company to the mandate of the people or sovereign shareholders. The public possibly know the policy agenda, such as: a series of issues to be resolved and its priorities, and public opportunities to provide influent input for the policy content. Likewise at the implementation stage, there is a room for the public to oversee deviations in implementation, and the existence of a mechanism for public control, a process that allows the public significantly discuss and influence a policy.

James E. Anderson defines policy as "a purposive course of action followed by an actor or set in dealing with a problem matter of concern". According to George C. Edward III and Ira Sharkansky, in line with Thomas R.'s opinion, public policy, " is what government says to do or not to do, it is goals or purposes of government programs ...". System theory states that public policy making cannot be separated from environmental influences. Dunn (2004) mentions 3 (three) policy elements: actors, environment, and public. Public policy is existed because of demands of a series of environmental influences, and then transformed into a political system. At the same time there are limitations and constraints of the environment that will influence policy makers. These environmental factors are socioeconomic characteristics, natural resources, climate, topography, demographics, culture and so on.

In short, public policy implies that the government has the most authority role in making policy, but policy making does not apply in a vacuum space. One of the main roles of government is the role of regulation. However, in a democratic state environment, this role is not always the dominant role of the government. All policy actors, government and non-government collectively can contribute.

In detail, Subarsono (2006) states that the policy framework is in reality determined by several aspects as follows:

a. "The goal will be achieved. It includes the complexity of the objectives achieved. If policy objectives are increasingly complex, it will be difficult to achieve the desired policy performance. Conversely, if the policy objectives are simpler, it is easier to achieve them.

b. The value preferences. What needs to be considered in policy making. A policy containing several value preferences will be more difficult to achieve than a policy that only pursues one value.

c. Resources supporting the policy. The performance of a policy will be determined by resources: financial, material and other infrastructure.

d. The ability of actors in making policy. The quality of a policy will be influenced by the quality of the actors involved in the process of making and determining the policy.

e. Environment such as social, economic, and political environments. Policy performance will be influenced by the social, economic, political context of the area or region.

f. The strategy used to reach the goal. The implementation strategy will affect the performance of the policy. It can be top-down or bottom-up approach; authoritarian, or democratic.

\section{Policy Evaluation}

Evaluation is usually intended to assess the effectiveness of public policies to be accountable to their constituents, the objectives achieved, and the gap between expectations and reality. According to Anderson in Winarno (2008: 166), in general policy evaluation is regarded as an activity that involves the estimation or assessment of policies. It includes the substance, implementation, and impact of the implementation of the policy. According to Lester and Stewart (Winarno, 2008: 166) "policy evaluation can be divided into two different tasks. The first task is to determine the consequences of a policy by describing its impact. Whereas, the second is to assess the success or failure of a policy based on predetermined standards or criteria".

\section{Policy Impact Evaluation Criteria}

Evaluating the impact of a program or public policy requires criteria to measure the success of the program or public policy. In the performance of policies to produce information there are criteria for evaluating the impact of public policies:

a. Effectiveness

According to Winarno (2002: 184), "Effectiveness comes from the word effective which means the achievement of success in achieving the goals set. Effectiveness is also called significance. It always relates to the relationship between the expected results and the results achieved".

b. Efficiency

According to Winarno (2002: 185), "Efficiency refers to the effort needed to produce a certain level of effectiveness. It, as a synonym of economic rationality, is a relationship between effectiveness and effort. It is generally measured by monetary cost. It is usually determined through the calculation of the cost per unit of product or service. Policies that achieve the highest effectiveness with the least cost are called efficiency." If the target to be achieved by a public policy is very simple while the cost spent for the policy process is too large compared to the results achieved, it means that the policy activity is wasteful and not feasible to be carried out. 


\section{c. Adequacy}

Winarno (2002: 186) states that "Adequacy in public policy is the goal achieved in fulfilling various things. It relates to the level of effectiveness that satisfies the needs, values, and opportunities that create problems. It also relates to effectiveness to measure or predict alternatives whether it can satisfy the needs, values, and opportunities in solving problems". The various problems come from a policy. So it can be concluded that the problem belongs to one of these types of problems. This means that before a policy product is approved and implemented, there must be a suitability analysis between the method implemented and the objectives achieved to identify whether the method of implementation is correct or violates the rules.

d. Alignment

According to Winarno (2002: 187), "Equality in public policy has the meaning of justice given and obtained from public policy objectives. It is closely related to legal and social rationality. It refers to the distribution of effects and effort between different groups in society. The policy oriented on equalization is a policy that the result or effort is fairly distributed. A certain program might be effective, efficient, and sufficient if the cost-benefit is evenly distributed".

e. Responsiveness

According Winarno (2002: 189), "Responsiveness in public policy is a response of an activity. It means the response of public policy objectives to the application of a policy. It relates to policy that can meet the needs, preferences, or values of certain groups of society. The success of the policy can be seen through community responses to the implementation after predicting the effect that will occur. The public response to the impact of the policy can be seen in the form of support or rejection". Responsiveness is important because the analysis can explain all other criteria like effectiveness, efficiency, adequacy, equality that do not meet the actual needs of the group about the benefit of the policy. Therefore, it is a real reflection of the needs, preferences, and values of a particular group against the effectiveness, efficiency, adequacy, and similarity.

f. Accuracy

According to Winarno (2002: 184), "Accuracy refers to the value or price of program objectives, and the strength of the assumptions that underlie the goal. It is used to select alternatives as recommendations to assess whether the results of the recommended alternatives are a viable choice of objectives. It relates to substantive rationality because it concerns with the substance of the goal rather than the way or instrument to realize that goal".

Based on the description above, the impact of the policy in this study is an assessment of the implementation of policies enacted by the government by evaluating the aspects of the impact of the policy such as the effectiveness, efficiency, adequacy, alignment, responsiveness and accuracy of policy implementation seen from the changes of various policies.

\section{The Principle of Village Autonomy}

Widjaja (2003: 165) states that village autonomy is genuine, round, and whole autonomy and not a gift from the government. On the other hand, the government is obliged to respect the original autonomy of the village. As a legal community unit that has an original arrangement based on the privileges, the village can carry out legal actions both public and civil law. The village has wealth, property, and can be prosecuted and sued in court. Village autonomy is the right, authority, and obligation to regulate and manage its own government affairs and community interests based on the origin and socio-cultural values that exist in the community. It aims to grow, develop, and follow the development of the village. Government affairs are based on the origin of the village. Regulations which become the authority of the regency or city government are handed over to the village. However, it must always be remembered that there are no rights without obligations, no authority without responsibility, and no freedom without limits. Therefore, in exercising rights, authority, and freedom in the implementation of village autonomy, it must continue to uphold the values of responsibility towards the United State of the Republic of Indonesia by emphasizing that villages are an inseparable part of the Indonesian nation and state. The exercise of the rights, authority and freedom of village autonomy requires responsibility to maintain the integrity, and unity of the nation in the Unitary State of Republic of Indonesia and the responsibility to realize the welfare of the people carried out in the corridor of applicable laws and regulations (Widjaja, 2003: 166).

Therefore, Article 19 of Law No. 6 of 2014 concerning Villages states that village authority includes:

a. authority based on original rights;

b. village-scale local authority;

c. authority assigned by the Government, Provincial Government, or Regency and City Government;

d. other authorities assigned by the Government, Provincial Government, or Regency and City Government in accordance with the provision rules.

Article 67 of Law No. 6 of 2014 also regulates the rights and obligations of villages, as follows:

(1) The village has the right:

a. to regulate and manage the interests of the community based on the rights of origin, customs and social and cultural values of the village community; 
b. to determine and manage village institutions;

c. to get a source of income.

(2) The village is obliged to:

a. protect and maintain the unity, and harmony of the village community in the context of national harmony and the integrity of the Unitary State of the Republic of Indonesia;

b. improve the quality of life of the village community;

c. develop democratic life;

d. develop village community empowerment; and

e. provide and improve services to the village community.

From the legal side, Bagir Manan states that autonomy is "the freedom and independence of the lower government units to regulate and manage some government affairs. The government affairs that may be governed and managed freely and independently become the domestic affairs of lower government units. Furthermore, freedom and independence in autonomy are not independence, but it deals with the greater unity. He further states that in terms of constitutional law, the form of an autonomous state is a subsystem of a unitary state. Therefore, autonomy is a phenomenon that exists in a unitary state. All understanding and content of autonomy are those of the unitary state. The unitary state is the foundation of the meaning and content of autonomy". (Bagir Manan quoted by Sukriono (2010); Diddi, 2013).

Kartohadikusumo, furthermore, states that to implement the autonomy, there must be inherent rights in the village:

"(1) the right to own territory with legal boundaries; (2) the right to elect and appoint the head of the village government; (3) the right to manage and regulate its own government and household; (4) the right to own and manage its own assets and finances; (5) the rights to own land; (6) the right to collect its own taxes. Without the inherent rights mentioned above, it is difficult to implement autonomy ". (Kartohadikusumo, 1984; Diddi, et al, 2013).

\section{RESEARCH METHOD}

This research is a descriptive research with a qualitative approach method. The research location is Pekarungan Village, Sukodono Sub-District, Sidoarjo District. The primary data are obtained by interview. The secondary data are obtained by searching for documents that match with the research theme. The focus of the research is: Is the Village Autonomy based on Law No. 6 of 2014 regarded to be effective and in accordance with the principle of autonomy. The Data are collected through key informant, the former head of Pekarungan Village from 1991 to 2006. This research is conducted in Pekarungan Village. Seen from the process of village formation, Pekarungan village is a mixed village category, a combination of geneological and administrative villages. So it is not a village formed by the government.

The data analysis technique of this study is a constant comparative method because the data analysis is compared to the changes in village autonomy policy by looking at the principles of village autonomy, especially for the authority of the village, which is based on government bureaucracy. In general, the process of data analysis includes: data reduction, data categorization, synthesis, and the preparation of working hypotheses.

\section{DISCUSSION}

Pekarungan Village is located at an altitude of $3 \mathrm{~m}$ above sea level, with rainfall of $2000 \mathrm{~mm} / \mathrm{year}$. It has 2 areas, namely Pekarungan and Karangnongko.

The existence of Village Law No. 6 of 2014 concerning Villages

Village Law No. 6 of 2014 was ratified with the aim of returning to the State confidence to the Village. It has been the object of development and "free area for sectoral projects" for the district and the Center government adjusted to its origins and customs. This law returns the village as an institution that has the right to regulate its own institutions. The Law is also a form of progress in the country's recognition of diverse villages.

The basic thinking for village governance is diversity, participation, genuine autonomy, democratization, and community empowerment. The government recognizes that the autonomy owned by the village through the Village Government can be given an assignment or delegation from the Government or Regional Government to carry out certain government affairs.

In fact, this law does not restore the village autonomy. The village remains as the object of development of the supra village. This situation can be seen from the existence of similar planning and budgeting applications through the Village Financial System (SISKEUDes). This system contains the use of village finance allowed by the government bureaucracy. For making plans, villages must refer to SISKEUDes. The final decision in planning and budgeting remains in the supra village not the village government itself. Referring to the principle of village autonomy, the village government should decide the planning and budgeting not the supra village. Based on the above conditions, the regulation of village financial usage makes the village authority even further with the principle of village autonomy. The village autonomy must not be equated with regional autonomy. But in reality, 
the implementation of village autonomy in Indonesia is equated with regional autonomy. It is a given autonomy not the original one. Dealing with the current form of autonomy, one of the Pekarungan Village Officials states that "the existence of Law No. 6 of 2014 is described as a head detachable but the tail is still held ". (key informant).

\section{E. CLOSING}

\section{Conclusion}

In the NKRI concept there is a relationship between the State as a supra village and the village itself. The relation is to determine the state's recognition of the village as an autonomous social unit not merely as a bureaucratic unit of the supra village. It is hoped that the relations between the state and the village will develop productive relations.

In fact, the understanding of village autonomy in Indonesia does not have a clear operational definition. Philosophically, village autonomy should be seen as an authority that already exists. It must grow from the village customs. It is not a given village or decentralization. On the other hand, village autonomy also means the ability of the community to regulate its own household matters that are formally and legally regulated by the central government through law.

Therefore, from the results of the evaluation, the village autonomy according to Law No. 6 of 2014 is ineffective because the goal of returning the village autonomy back to the village is not achieved. The village is still under the supra village or government bureaucracy. The policy of village autonomy does not touch its concept, especially in the authority of village financial management. There is a doubt of the Central Government in determining the village autonomy form. As a result, it affects the policies taken by the Government. The policy of village autonomy in Indonesia is still based on economic and political interests.

\section{Suggestion}

It is time for village autonomy to be returned to the village, so the village can be independent. The power and responsibility to manage the household must be given to the village government. The village is placed as the main actor who is fully responsible for making planning and implementing the village development. The Central and Regional Governments are obliged to provide subsidies to the village in the form of no taxes for farmers, motivating them to move to agriculture or other fields according to the conditions of the villages, and building basic facilities to eliminate isolation to village. Central and Local Governments have only policies and program planning but the final decision to determine the program to be implemented must be decided by the village.

\section{BIBLIOGRAPHY}

Agusta, Ivanovich dkk, 2014. Indeks Kemandirian Desa Metode, Hasil dan Alokasi Program Pembangunan, Jakarta: Yayasan Pustaka Obor, 2014), h.34

Kleintjes., (1929). Staatsinstellingen van Nederlandsche-Indie. Tweede Deel Amsterdam, J.H. de Bussy, derde druk, dalam Aries Djaenuri, dkk, Sistem Pemerintahan Desa,Tangerang Selatan, Penerbit Universitas Terbuka, Cetakan 10, 2018

Kusuma, A.S., (1951). Desa Pradja Sebagai Sendi Masyarakat. Surabaya: Badan Penerbit Nasional.

Lindawaty, Debora Sanur; Dukungan Pemerintah Terhadap Otonomi Desa : Perbandingan Indonesia dan Cina; Jurnal Politica Vol. 3, No. 2, November 2012

Madjloes., (1981). Mempelajari Kedudukan dan Peranan Peradilan Desa Dalam Rangka Menuju Desa Pancasila. Jakarta: Pidato Wisuda ke-IX-IIP. Depdagri.

Martohardojo, M., (1959). Beberapa Undang-undang dan Peraturan-peraturan Dalam Pemerintahan Desa. Surabaya: Tata Usaha Madjalah Pamong, Tjetakan ke-6.

Moloeng, Lexy. J, Metode Penelitian Kualitatif, Remaja Rosdakarya, Bandung, 2001.

Saefullah A. Djaja, Modernisasi Perdesaan Dampak Mobilitas Penduduk, AIPI Bandung, Bandung, 2008

Sakinah Nadir, Otonomi Daerah dan Desentralisasi Desa, Jurnal Politik Profetik Volume 1 Nomor1 Tahun 2013.

Samudra Wibawa, Kebijakan Publik, Proses dan Analisis, Intermedia, Jakarta, 1994.

Saparin, Sumber., (1977). Tata Pemerintahan dan Administrasi Pemerintahan Desa. Jakarta: Ghalia Indonesia.

Sihombing, Frans Bona., (1991). Himpunan Peraturan Lengkap Tentang Desa dan Kelurahan. Jakarta: Sinar Grafika.

Subarsono, AG, Drs,M.Si, MA, Analisis Kebijakan Publik, Pustaka Pelajar, Yogyakarta, 2005.

Soetardjo, (1965). Desa. Bandung: Sumur Bandung.

Sunardjo, Unang., (1984). Tinjauan Singkat Tentang: Pemerintahan Desa dan Kelurahan. Bandung: Tarsito. Suryaningrat, Bayu., (1976). Pemerintahan dan Administrasi Desa, Bandung: Mekar Jaya.

Suryaningrat, Bayu., (1980). Desa dan Kelurahan, Penyelenggaraan Pemerintahannya. Jakarta: Metro Pos. Suhardjo A.J, dkk. 2008. Geografi Perdesaan, Sebuah Antropologi; (Yogyakarta; IdeAs Media, 2008), h.16 Taufane Taufik, Pengelolaan Keuangan Desa dalam Sistem Keuangan Republik Indonesia, http://academia.edu/taufanetaufik.html, tanggal 27 Agustus 2015.

Widjaja, HAW. Otonomi Desa : Merupakan Otonomi yang Asli, Bulat dan Utuh. Jakarta: PT RajaGrafindo 
Persada, Cet. 7, 2014.

Zainal, Jurnal TAPIs Vol.12 No.1 Januari-Juni 2016

Buku Saku Dana Desa

Indeks Desa Membangun

Menuju Masyarakat Yang Cukup Sejahter-Prestasi Pertanian Republik Rakyat Tiongkok Dalam 60 Tahun Terakhir, http://indonesian.cri.cn/281/2009/05/27/1s9695.htm

https://sekolahdesa.or.id/aturan-pengelolaan-keuangan-desa-berubah-ambisi-teknokrasi-desa

UNDANG-UNDANG REPUBLIK INDONESIA NOMOR 19 TAHUN 1965 TENTANG DESAPRAJA SEBAGAI BENTUK PERALIHAN UNTUK MEMPERCEPAT TERWUJUDNYA DAERAH TINGKAT III DI SELURUH WILAYAH REPUBLIK INDONESIA

UNDANG-UNDANG REPUBLIK INDONESIA NOMOR 6 TAHUN 2014 TENTANG DESA

PERATURAN MENTERI DALAM NEGERI REPUBLIK INDONESIA NOMOR 20 TAHUN 2018 TENTANG PENGELOLAAN KEUANGAN DESA

PERATURAN BUPATI SIDOARJO NOMOR 113 TAHUN 2018 TENTANG PEDOMAN PENGELOLAAN KEUANGAN DESA 